\title{
Malignant Histiocytosis
}

National Cancer Institute

\section{Source}

National Cancer Institute. Malignant Histiocytosis. NCI Thesaurus. Code C7202.

An antiquated term referring to cases of systemic non-Hodgkin lymphomas which are composed of large, atypical neoplastic lymphoid cells and cases of hemophagocytic syndromes. In the past, cases of anaplastic large cells lymphoma were called malignant histiocytosis. 